\title{
ASOSIASI ANTARA TUTUPAN KOMUNITAS KARANG DENGAN KOMUNITAS IKAN TERUMBU KARANG DI PESISIR TIMUR PULAU BIAK, KABUPATEN BIAK NUMFOR
}

\section{ASSOCIATION BETWEEN CORAL COMMUNITY COVER WITH CORAL REEF FISH COMMUNITIES AT EAST COAST OF BIAK ISLAND, BIAK NUMFOR REGENCY}

\author{
Olivia L.Y. Rumkorem ${ }^{1 *}$, Rahmat Kurnia ${ }^{2}$ dan Fredinan Yulianda ${ }^{2}$ \\ ${ }^{1}$ Program Studi Pengelolaan Sumberdaya Pesisir dan Lautan, FPIK-IPB, Bogor, 16680 \\ ${ }^{2}$ Departemen Manajemen Sumberdaya Perairan, FPIK-IPB, Bogor, 16680 \\ "E-mail: olivialyr7@gmail.com
}

\begin{abstract}
Coral reef ecosystems have many benefits including protect the coast from strong waves and currents and are important in maintaining the ecological system in these waters as habitat, spawning grounds, shelter and food sources for marine biota such as ascidians, sponge, echinoderms, mollusks, and fish. The diversity of reef fishes on the east coast of Biak Island is one of the important resources used as a source of income or food source by residents who earn a living as fishermen. This study aims to analyze the relationship between coral communities and coral reef fish communities on the east coast of Biak Island, Biak Numfor Regency. Observations were done by diving using SCUBA equipment. Observation of the condition of the coral reefs used the PIT (Point Intercept Transect) method and coral reef fish worked by the UVC (Underwater Visual Census) method. Data analysis was running by the Spearman test analysis. The results showed that changes in coral community cover affect reef fish communities. This study concludes that there is an association between coral communities and coral reef fish communities that have a positive linear relationship.
\end{abstract}

Keywords: association, Biak Numfor, coral fish, coral reef

\begin{abstract}
ABSTRAK
Ekosistem terumbu karang memiliki banyak manfaat termasuk melindungi pantai dari gelombang dan arus yang kuat serta penting dalam menjaga sistem ekologi di perairan yaitu sebagai habitat, tempat pemijahan, tempat berteduh dan sumber makanan untuk biota laut seperti ascidian, spons, echinodermata, moluska, dan ikan. Keanekaragaman ikan karang di pesisir timur Pulau Biak adalah salah satu sumberdaya penting yang dimanfaatkan sebagai sumber pendapatan atau sumber makanan oleh penduduk yang mencari nafkah sebagai nelayan. Penelitian ini bertujuan untuk menganalisis hubungan antara komunitas karang dan komunitas ikan karang di pesisir timur Pulau Biak, Kabupaten Biak Numfor. Pengamatan dilakukan dengan menyelam menggunakan peralatan SCUBA. Pengamatan kondisi terumbu karang menggunakan metode PIT (Point Intercept Transect) dan ikan terumbu karang dengan metode UVC (Underwater Visual Census). Analisis data dilakukan dengan analisis uji Spearman. Hasil penelitian menunjukkan bahwa perubahan tutupan komunitas karang mempengaruhi komunitas ikan karang. Kesimpulan dari penelitian ini adalah terdapat asosiasi antara komunitas karang dan komunitas ikan karang yang memiliki hubungan linier positif.
\end{abstract}

Kata Kunci: asosiasi, Biak Numfor, ikan karang, terumbu karang

\section{PENDAHULUAN}

Pulau Biak merupakan salah satu pulau di Kabupaten Biak Numfor yang terletak di sebelah utara daratan Papua dan berbatasan langsung dengan Samudera Pasifik. Posisi ini menjadikan Pulau Biak kaya akan potensi sumber daya pesisir dan lautan. Potensi tersebut antara lain potensi ekologi, sosial budaya dan ekonomi. Potensi 
ekologi meliputi ekosistem mangrove, padang lamun, terumbu karang dan ikan karang. Menurut DKP (2016), ekosistem potensial yang terdapat di Pulau Biak adalah mangrove seluas 5317,61 ha, padang lamun seluas 2038,61 ha dan terumbu karang seluas 9620,40 ha. Ekosistem terumbu karang merupakan salah satu ekosistem yang tersebar cukup luas dan dapat ditemukan hampir semua wilayah perairan di pesisir timur Pulau Biak.

Terumbu karang merupakan ekosistem yang memiliki peranan penting secara ekologis, sosial dan ekonomi. Secara ekologis, ekosistem ini berperan sebagai habitat, daerah pemijahan dan mencari makan serta proses-proses ekologis dari beranekaragam biota laut. Selain itu, ekosistem ini juga berperan penting sebagai pelindung kawasan pesisir dari hempasan ombak dan gerusan arus serta sebagai industri pariwisata. Disamping peranan penting tersebut, terumbu karang mengalami ancaman degradasi bahkan kepunahan. Ancaman terhadap ekosistem terumbu karang saat ini telah terjadi diseluruh dunia, termasuk di pesisir Pulau Biak. Secara umum, dalam kurun waktu 6 tahun (20082014) persentase tutupan karang hidup di Pulau Biak mengalami penurunan sebesar 23,93\% (Khairudi, 2016). Secara khusus, penelitian terkait telah dilakukan oleh LIPI (2016) di pesisir bagian timur Pulau Biak dan menyimpulkan bahwa telah terjadi perubahan tutupan karang dalam kurun waktu 3 tahun (2014-2016) sebesar 1,94\%. Penurunan persentase tutupan karang ini mengindikasikan terjadinya kerusakan ekosistem terumbu karang. Aktivitas eksploitasi sumber daya laut dengan menggunakan alat tangkap yang tidak ramah lingkungan merupakan salah satu penyebab utama kerusakan terumbu karang di pesisir timur Pulau Biak. Ekosistem terumbu karang telah berkontribusi terhadap tingginya keaneka-ragaman ikan yang kelangsungan hidupnya bergantung pada karang. Kelimpahan ikan karang yang ditemukan di pesisir timur Pulau Biak pada tahun 2008 berkisar antara $96-479 \mathrm{ind} / 250 \mathrm{~m}^{2}$ dan pada tahun 2014 berkisar antara 296-793 ind $/ 250 \mathrm{~m}^{2}$. Bentuk pertumbuhan karang yang ditemukan berkisar 2-9 jenis, serta total genus yang ditemukan sebanyak 26 genus dengan Porites sebagai genus yang paling dominan (Khairudi, 2016).

Famili ikan yang ditemukan terdiri atas Famili Chaetodontidae, Acanthuridae, Scaridae, Lutjanidae, Caesionidae, Mullidae, Serranidae, Nemipteridae, Lethrinidae, Siganidae, Haemulidae dan Kyphosidae. Jenis ikan yang ditemukan berkisar antara 56-71 jenis dengan kelimpahan ikan berkisar antara 1928-2458 individu (LIPI, 2014; LIPI, 2016).

Keanekaragaman ikan karang di pesisir timur Pulau Biak termasuk salah satu sumber daya penting yang di-manfaatkan sebagai sumber makanan dan sumber pendapatan oleh penduduk se-tempat sebagai nelayan. Jenis dan kelimpahan ikan karang di pesisir timur Pulau Biak pada tahun 20142015 mengalami peningkatan masing-masing $21 \%$, sedangkan pada tahun 2015-2016 jenis ikan mengalami penurunan sebesar $10 \%$ dan kelimpahan ikan sebesar 21,5\% (LIPI, 2016). Berdasarkan hasil penelitian LIPI (2014), LIPI (2016) dan Khairudi (2016), keragaman jenis dan kelimpahan ikan terumbu karang di pesisir timur Pulau Biak mengalami perubahan seiring dengan perubahan persentase tutupan karang. Hal ini didukung oleh Komyakova (2018) yang menyimpulkan bahwa kekayaan dan kelimpahan spesies ikan meningkat ketika ukuran koloni karang meningkat.

Informasi mengenai persentase tutupan karang dan ikan karang di pesisir timur Pulau Biak sudah tersedia, namun pengetahuan mengenai hubungan antara komunitas karang dan ikan karang belum lengkap. Sementara, sumber mata pencaharian utama masyarakat di pesisir timur Pulau Biak adalah sebagai nelayan yang sangat bergantung pada sumber daya terumbu karang dan ikan yang berasosiasi 
didalamnya. Selain itu, Pemerintah Daerah Kabupaten Biak Numfor dalam rencana zonasi pencadangan KKPD Pulau Biak telah menetapkan daerah pesisir timur Pulau Biak sebagai zona pemanfaatan yang diperuntukan bagi wisata bahari dengan memanfaatkan terumbu karang dan ikan karang sebagai objek wisata. Jenis wisata bahari yang dimaksud antara lain wisata snorkeling dan selam. Oleh sebab itu, dibutuhkan informasi lebih lengkap yang tidak hanya terkait kondisi terumbu karang dan ikan karang, namun juga penting untuk menganalisis hubungan antar keduanya. Berdasarkan hal tersebut, penting untuk melakukan penelitian ini dengan tujuan untuk menganalisis asosiasi antara persentase tutupan komunitas karang dan komunitas ikan karang.

\section{METODE PENELITIAN}

\subsection{Waktu dan Tempat}

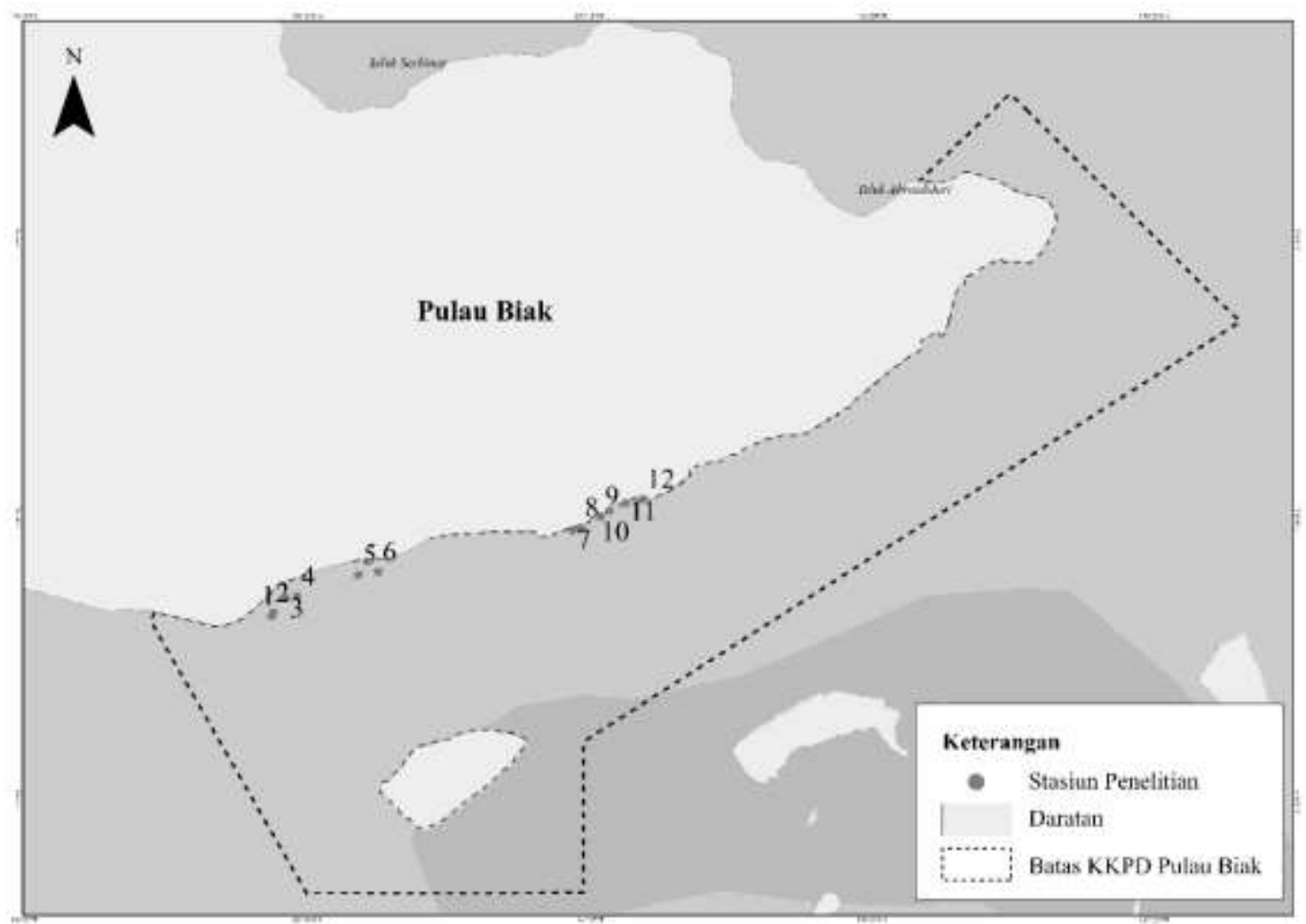

Gambar 1. Lokasi penelitian.
Penelitian dilaksanakan pada bulan Mei sampai Juli 2017 di pesisir timur Kabupaten Biak Numfor (Gambar 1). Terdapat 12 lokasi penelitian yang ditetapkan berdasarkan tutupan karang dengan melakukan analisis Citra Landsat 8 dan disesuaikan dengan rencana zonasi dalam pencadangan Kawasan Konservasi Perairan Daerah (KKPD) Pulau Biak. Lokasi-lokasi tersebut masuk dalam zona pemanfataan yang diperuntukkan bagi pengembangan pariwisata bahari. Lokasi penelitian meliputi Kampung Anggraidi, Ruar, Ibdi, Soryar, Aryom, Opiaref dan Yensama (Tabel 1). Titik pengambilan data disesuaikan dengan kondisi topografi lokasi penelitian yang landai hingga kemiringan terjal. Pengambilan data di setiap lokasi dilakukan pada 2 kedalaman yakni $3 \mathrm{~m}$ yang mewakili daerah rataan terumbu (reef flat) dan $7 \mathrm{~m}$ yang mewakili daerah tubir (reef slope). Pengambilan data dilakukan saat perairan dalam kondisi pasang. 
Tabel 1. Lokasi penelitian.

\begin{tabular}{|c|c|c|c|c|c|}
\hline \multirow{3}{*}{$\begin{array}{l}\text { Kode } \\
\text { Lokasi }\end{array}$} & \multirow{3}{*}{$\begin{array}{l}\text { Nama } \\
\text { Lokasi }\end{array}$} & \multicolumn{4}{|c|}{ Titik Koordinat } \\
\hline & & \multicolumn{2}{|c|}{$3 \mathrm{~m}$} & \multicolumn{2}{|c|}{$7 \mathrm{~m}$} \\
\hline & & Longitude & Latitude & Longitude & Latitude \\
\hline 1 & Anggraidi 1 & 136.15606 & -1.19508 & 136.15609 & -1.19508 \\
\hline 2 & Anggraidi 2 & 136.15669 & -1.19405 & 136.15671 & -1.19407 \\
\hline 3 & Anggraidi 3 & 136.16010 & -1.18969 & 136.16013 & -1.18971 \\
\hline 4 & Anggraidi 4 & 136.16936 & -1.18356 & 136.16948 & -1.18360 \\
\hline 5 & Ruar & 136.18169 & -1.18276 & 136.18171 & -1.18281 \\
\hline 6 & Ibdi & 136.18764 & -1.18192 & 136.18767 & -1.18214 \\
\hline 7 & Soryar & 136.24488 & -1.16983 & 136.24488 & -1.16985 \\
\hline 8 & Aryom 1 & 136.24726 & -1.16891 & 136.24728 & -1.16892 \\
\hline 9 & Aryom 2 & 136.24858 & -1.16825 & 136.24860 & -1.16827 \\
\hline 10 & Opiaref 1 & 136.25320 & -1.16551 & 136.25323 & -1.16551 \\
\hline 11 & Opiaref 2 & 136.25568 & -1.16401 & 136.25569 & -1.16403 \\
\hline 12 & Yensama & 136.26558 & -1.16046 & 136.26559 & -1.16049 \\
\hline
\end{tabular}

\subsection{Metode Pengumpulan Data}

Data yang dikumpulkan terdiri dari data primer dan data sekunder. Data primer berupa data kualitas perairan, bentuk pertumbuhan dan kondisi terumbu karang serta jumlah individu dan jumlah ikan terumbu karang. Sedangkan data sekunder merupakan data-data pendukung berupa profil daerah dan data kualitas perairan seperti kecerahan perairan, kadar oksigen terlarut (DO) dan kekeruhan yang diperoleh melalui berbagai sumber seperti buku dan laporan tahunan dari instansi terkait yakni Badan Perencanaan Pembangunan Daerah (BAPPEDA) serta Dinas Kelautan dan Perikanan Kabupaten Biak Numfor. Alat yang digunakan dalam penelitian ini yaitu termometer, secchi disk, termometer, Global Positioning System (GPS), alat SCUBA, kamera bawah air, roll meter, alat tulis, sabak dan kertas anti air.

Data kualitas perairan dibutuhkan untuk mengetahui kondisi lingkungan perairan di lokasi penelitian. Kondisi lingkungan perairan menjadi salah satu faktor pembatas yang mempengaruhi tingkat pertumbuhan dan perkembangan terumbu karang. Faktor fisik dan kimia lingkungan perairan yang menjadi pembatas antara lain cahaya, kedalaman, suhu, salinitas, kecerahan dan substrat. Parameter yang diukur untuk mendukung data kualitas perairan yaitu suhu, salinitas serta kecerahan perairan.

Pengumpulan data terumbu karang dilakukan dengan cara penyelaman dan menggunakan metode Point Intercept Transect (PIT). Metode PIT dilakukan dengan mencatat substrat bentik disepanjang garis transek yang lurus dengan interval tetap, dimana interval yang paling sering digunakan adalah $10 \mathrm{~cm}, 25 \mathrm{~cm}$ dan $50 \mathrm{~cm}$ (Falcon et al., 2015). Transek yang digunakan pada penelitian ini adalah sepanjang $25 \mathrm{~m}$ yang dibentangkan sejajar garis pantai dengan interval $50 \mathrm{~cm}$ dan dilakukan pengulangan sebanyak dua kali (Giyanto et al., 2014).

Pengambilan data ikan terumbu karang diperoleh melalui metode Underwater Visual Census (UVC). Metode UVC dilakukan dengan cara sensus terhadap ikan terumbu karang yang dijumpai pada transek sepanjang $25 \mathrm{~m}$ dengan ulangan sebanyak dua kali dan dengan batas pengamatan ke kanan dan kiri masing-masing 2,5 m. Metode UVC merupakan salah satu metode yang dapat digunakan untuk mengukur distribusi, kekayaan jenis ikan, kelimpahan dan ukuran ikan di habitat laut dangkal, yang mana tingkat optimal metode ini bervariasi, 
tergantung pada tujuan pengamatan, tingkat kemahiran pengamat dalam mengidentifikasi ikan, kecerahan perairan, kedalaman perairan, tipe habitat, kecepatan arus dan gelombang (Edgar et al., 2004).

\subsection{Analisis Data}

\subsubsection{Tutupan Komunitas Karang}

Pengolahan data komunitas karang menggunakan metode PIT (Falcon et al., 2015), sedangkan kategori tutupan komunitas karang mengacu pada Gomez and Yap (1988) (Tabel 1).

\section{$\%$ Tutupan Komunitas Karang = $\frac{\text { Jumlah titik per lkomunitas }}{\text { (Total titik pengamatan) }} \times 100 \%$}

Tabel 2. Kriteria kondisi terumbu karang.

\begin{tabular}{ccl}
\hline No. & $\begin{array}{c}\text { Persentase tutupan } \\
\text { komunitas karang }(\%)\end{array}$ & Kategori \\
\hline 1 & $75-100$ & Sangat baik \\
2 & $50-74,9$ & Baik \\
3 & $25-49,9$ & Sedang \\
4 & $0-24,9$ & Rusak \\
\hline
\end{tabular}

\subsubsection{Ikan Terumbu Karang}

Data pengamatan ikan terumbu karang yang diperoleh di lapangan kemudian diolah dan dianalisis menggunakan perangkat lunak berupa program Microsoft excel. Untuk mengetahui kondisi komunitas ikan digunakan beberapa analisis, yaitu indeks keanekaragaman jenis, indeks keseragaman dan indeks dominansi. Nilai indeks keanekaragaman Shannon $\left(\mathrm{H}^{\prime}\right)$, indeks keseragaman (E) dan indeks dominansi (C) serta kriteria dari nilai masing-masing dapat dilihat pada Tabel 2 (Odum, 1971):

- Indeks keanekaragaman ShannonWiener:

$$
\mathrm{H}^{\mathrm{N}}=-\Sigma\left(\frac{\mathrm{n}_{\mathrm{i}}}{\mathrm{N}}\right) \times \operatorname{Ln}\left(\frac{\mathrm{n}_{\mathrm{i}}}{\mathrm{N}}\right)
$$

- Indeks keseragaman:

$$
\mathrm{E}=\frac{\mathrm{H}^{\circ}}{\ln \mathrm{S}}
$$

- Indeks dominansi:

$$
\mathrm{C}=\Sigma\left(\frac{\mathrm{n}_{\mathrm{s}}}{\mathrm{N}}\right)^{2}
$$

\section{Keterangan:}

$\mathrm{H}^{\prime}$ = Indeks Keanekaragaman

$\mathrm{E}=$ Indeks Keseragaman

$\mathrm{C}=$ Indeks Dominansi

$\mathrm{n}_{\mathrm{i}}=$ Jumlah individu ikan per spesies

$\mathrm{N}=$ Jumlah total individu ikan

$\mathrm{S}=$ Jumlah spesies

Tabel 3. Kriteria nilai struktur komunitas ikan terumbu karang.

\begin{tabular}{lll}
\hline \multicolumn{1}{c}{ Indeks } & Kisaran & Kategori \\
\hline $\begin{array}{l}\text { Keanekaragaman } \\
\left(\mathrm{H}^{\prime}\right)\end{array}$ & $\mathrm{H}^{\prime} \leq 2$ & Rendah \\
& $2,0<\mathrm{H}^{\prime} \leq$ & Sedang \\
& 3 & \\
& $\mathrm{H}^{\prime} \geq 3,0$ & Tinggi \\
Keseragaman (E) & $0,00<\mathrm{E} \leq$ & Komunitas \\
& 0,50 & Tertekan \\
& $0,50<\mathrm{E} \leq$ & Komunitas \\
& 0,75 & Labil \\
& $0,75<\mathrm{E} \leq$ & Komunitas \\
& 1,00 & Stabil \\
& $0,00<\mathrm{C} \leq$ & Rendah \\
Dominansi $(\mathrm{C})$ & 0,50 & \\
& $0,50<\mathrm{C} \leq$ & Sedang \\
& 0,75 & \\
& $0,75<\mathrm{C} \leq$ & Tinggi \\
& 1,00 & \\
\hline
\end{tabular}

\subsubsection{Hubungan Komunitas Karang dengan Jenis dan Kelimpahan Ikan Terumbu Karang}

Hubungan antara komunitas karang dengan komunitas ikan karang menggunakan uji korelasi Spearman.

\section{HASIL DAN PEMBAHASAN}

\subsection{Kondisi Perairan}

Pesisir bagian timur Pulau Biak Kabupaten Biak Numfor memiliki beberapa 
area perairan yang telah ditetapkan sebagai zona pemanfaatan. Area tersebut diperuntukkan bagi pengembangan pariwisata bahari pada rencana zonasi dalam pencadangan Kawasan Konservasi Perairan Daerah (KKPD) Pulau Biak. Pulau Biak dikelilingi oleh laut yang relatif dalam. Kedalaman laut di pesisir timur Pulau Biak berkisar antara 0-405 $\mathrm{m}$ dan tinggi gelombang laut berkisar antara 1,12-1,21 m yang dipengaruhi oleh pola arus dari Samudera Pasifik sebelah timur.

Kondisi perairan di setiap lokasi pengamatan berada dalam batas tolerasi untuk pertumbuhan terumbu karang dan biota lainnya yang berasosiasi dengan terumbu karang. Suhu permukaan berkisar antara $28^{\circ}-$ $30^{\circ} \mathrm{C}$ dengan nilai rata-rata $29,2^{\circ} \mathrm{C}$. Salinitas berkisar antara 30-34 ppm dengan rata-rata $32 \mathrm{ppm}$. Kecepatan arus berkisar antara $0,052-0,245 \mathrm{~m} / \mathrm{s}$ dengan nilai rata-rata 0,138 $\mathrm{m} / \mathrm{s}$, dan kecerahan mencapai kedalaman lebih dari $15 \mathrm{~m}$ dan menurut data laporan DKP Kabupaten Biak Numfor, nilai kekeruhan sangat rendah (0 NTU) kecuali disekitar muara sungai Ruar yang memiliki nilai kekeruhan 1 NTU, namun nilai ini masih tergolong dalam perairan jernih. Ratarata kadar oksigen terlarut (DO) $5,4 \mathrm{ppm}$ dengan kisaran 5,18-5,75 ppm. Menurut Guan et al. (2015) kisaran suhu optimal untuk pertumbuhan terumbu karang adalah $21,7-29,6^{\circ} \mathrm{C}$ dan salinitas tahunan berkisar 28,7-40,4 ppm.

\subsection{Kondisi Terumbu Karang}

Terumbu karang di Kabupaten Biak Numfor termasuk tipe karang tepi (fringing reef). Menurut Turner et al. (2009) terumbu karang tepi merupakan terumbu karang yang tumbuh di pesisir pantai pulau besar ke arah laut. Ekosistem terumbu karang di Pulau Biak memiliki topografi rataan terumbu yang tipis dan berakhir tubir dengan kedalaman 3$15 \mathrm{~m}$.

Hasil pengamatan kondisi tutupan komunitas karang pada setiap lokasi disajikan pada Gambar 2. Tutupan komunitas karang tertinggi pada kedalaman $3 \mathrm{~m}$ terdapat di Ibdi (65\%, kategori baik), dan terendah terdapat di Anggraidi 4 (20\%, kategori buruk). Tutupan komunitas karang tertinggi pada kedalaman $7 \mathrm{~m}$ terdapat di Opiaref 1 (50\%, kategori baik) dan terendah terdapat di Anggraidi 4 (10\%, kategori buruk). Dapat disimpulkan bahwa komunitas karang di Anggraidi 4 pada kedua kedalaman dalam kondisi tidak terjaga dengan baik dan hal ini menunjukkan adanya indikasi bahwa rendahnya persentase tutupan komunitas karang pada lokasi tersebut. Hal itu disebabkan oleh adanya aktivitas perikanan dan wisata yang tidak ramah lingkungan serta pembuangan limbah rumah tangga ke laut dan pembuangan jangkar perahu dengan sembarangan.

Praktik destructive fishing seperti penggunaan bahan peledak, racun dan kerusakan oleh jangkar juga merupakan beberapa ancaman serius bagi komunitas ikan dan kerusakan fisik terumbu karang sebagai habitatnya. Menurut Saila et al. (1993) total kerusakan area tutupan karang meningkat seiring dengan peningkatan laju perusakan karang oleh destructive fishing. Semakin tinggi tingkat kerusakan, maka periode pemulihan semakin panjang, namun tidak mengembalikan kondisi terumbu karang seperti kondisi awal sebelum terjadi kerusakan.

\subsection{Komunitas Ikan Terumbu Karang}

Total ikan terumbu karang yang ditemukan pada kedalaman $3 \mathrm{~m}$ sebanyak 2792 ekor yang termasuk dalam 31 genera dan 14 famili. Pada kedalaman $7 \mathrm{~m}$ ditemukan sebanyak 2259 ekor yang termasuk dalam 33 genera dan 14 famili yang tersebar pada 12 lokasi pengamatan. Komposisi famili ikan terumbu karang yang ditemukan di lokasi penelitian disajikan pada Gambar 3. Secara keseluruhan, jumlah ikan tertinggi berasal dari Famili Acanthuridae, Caesionidae, Chaetodontidae dan Pomacentridae. 


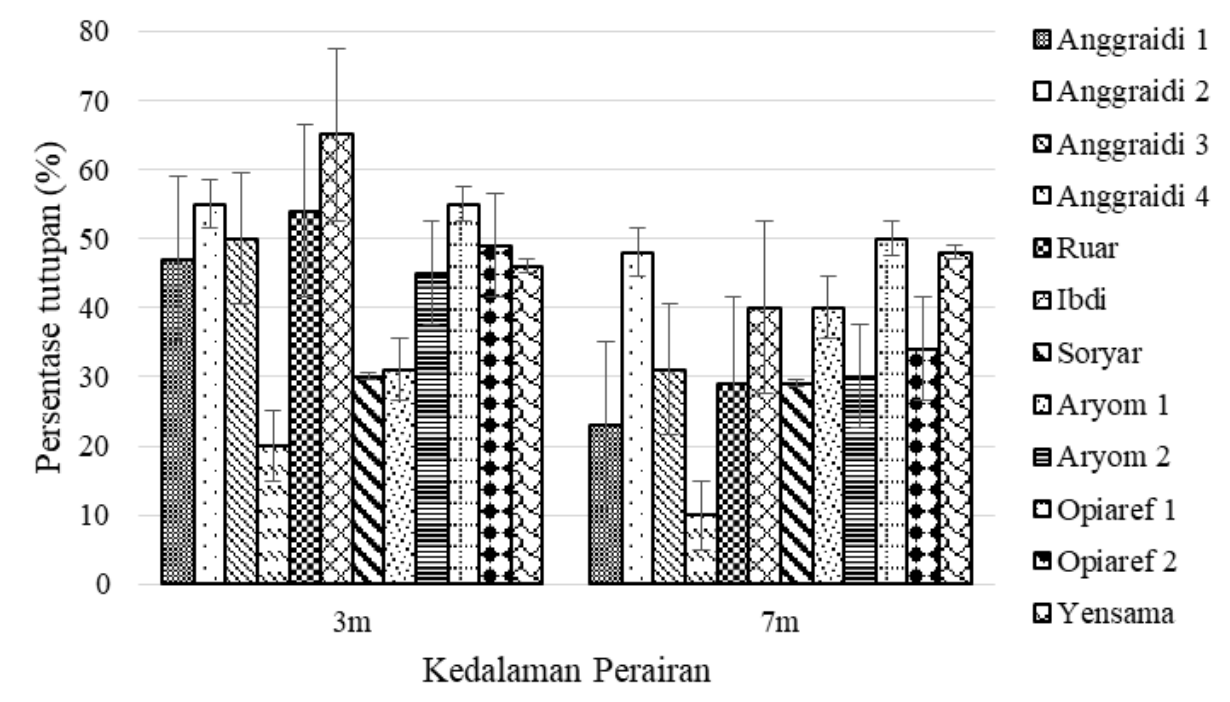

Gambar 2. Persentase tutupan komunitas karang pada kedalaman $3 \mathrm{~m}$ dan $7 \mathrm{~m}$.

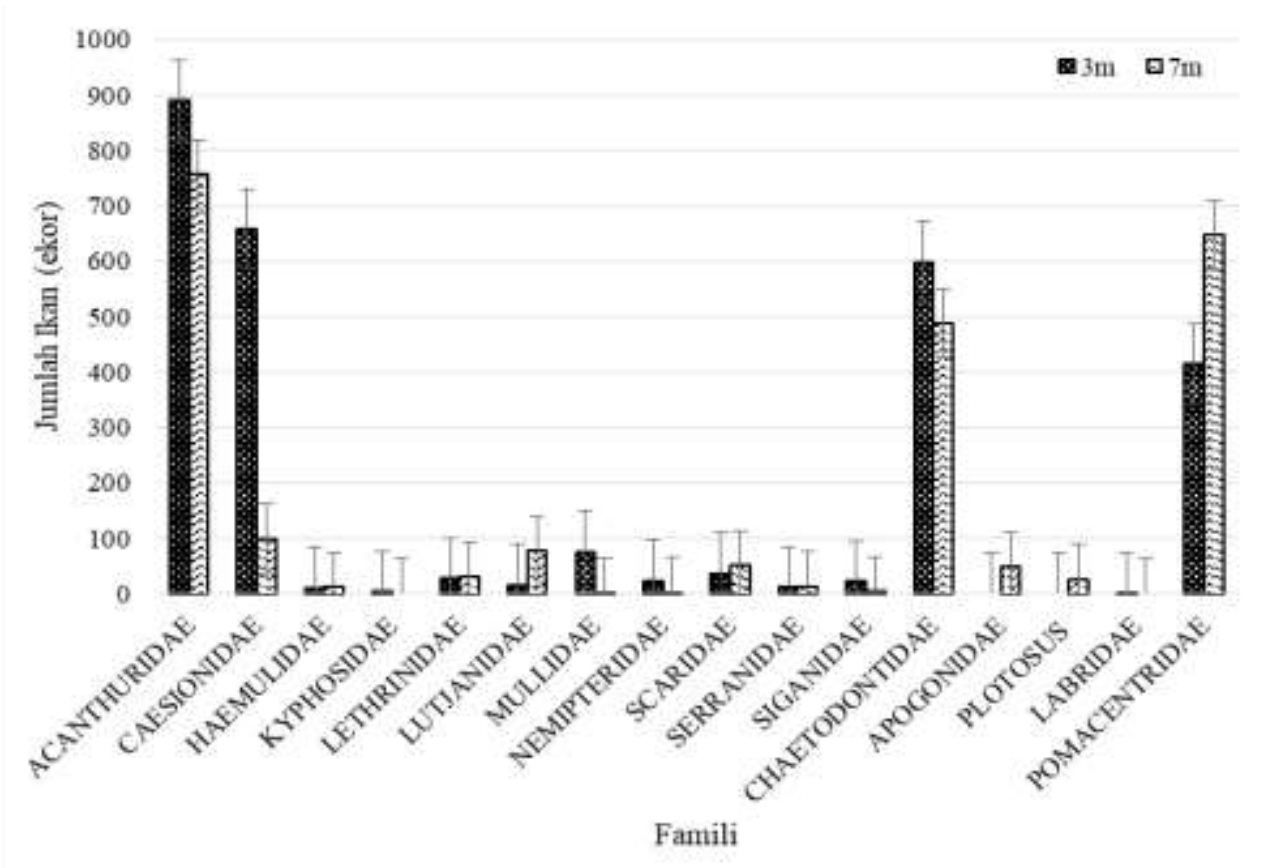

Gambar 3. Komposisi famili ikan terumbu karang dengan jumlah ikan.

Jumlah individu ikan paling banyak ditemukan pada kedalaman $3 \mathrm{~m}$ berasal dari Famili Acanthuridae sebanyak 890 ekor atau dengan persentase 31,9\%, Famili Caesionidae sebanyak 658 ekor $(23,6 \%)$, Famili Chaetodontidae sebanyak 599 ekor $(21,5 \%)$ dan Famili Pomacentidae sebanyak 414 ekor $(14,8 \%)$, sedangkan jumlah individu dari Famili yang lainnya masingmasing kurang dari 200 ekor atau memiliki persentase masing-masing kurang dari $10 \%$ dari total individu yang ditemukan.

Jumlah individu ikan yang ditemukan pada kedalaman 7 m sebanyak 757 ekor dan berasal dari Famili Acanthuridae (33,5\%), sedangkan Famili Pomacentridae ditemukan sebanyak 647 ekor (28,6\%), dan Famili Chaetodontidae sebanyak 488 ekor $(21,6 \%)$. Famili yang lainnya ditemukan kurang dari 200 ekor atau memiliki persentase masing- 
masing kurang dari $10 \%$ dari total individu yang ditemukan.

Ikan terumbu karang diklasifikan menjadi 3 kelompok yaitu ikan target, ikan indikator dan ikan mayor. Ikan target yang ditemukan di pesisir timur Pulau Biak adalah dari Famili Acanthuridae, Caesionidae, Haemulidae, Kyphosidae, Lethrinidae, Lutjanidae, Mullidae, Nemipteridae, Scaridae, Serranidae dan Siganidae. Sedangkan ikan indikator yang ditemukan adalah Famili Chaetodontidae, serta ikan mayor yang ditemukan adalah dari Famili Apogonidae, Labridae, Plotosus dan Pomacentridae. Komposisi kelimpahan ikan terumbu karang baik pada kedalaman $3 \mathrm{~m}$ maupun $7 \mathrm{~m}$ disajikan pada Gambar 4. Grafik pada gambar tersebut dapat dilihat bahwa pada kedua kedalaman didominasi oleh ikan target. Persentase komposisi kelimpahan ikan terumbu karang yang ditemukan pada kedalaman $3 \mathrm{~m}$ terdiri dari ikan target sebesar $63,6 \%$, ikan indikator $21,5 \%$ serta ikan mayor $14,9 \%$, dan persentase pada kedalaman $7 \mathrm{~m}$ terdiri dari ikan target $46,5 \%$, ikan indikator $25,4 \%$ serta ikan mayor $28,2 \%$.

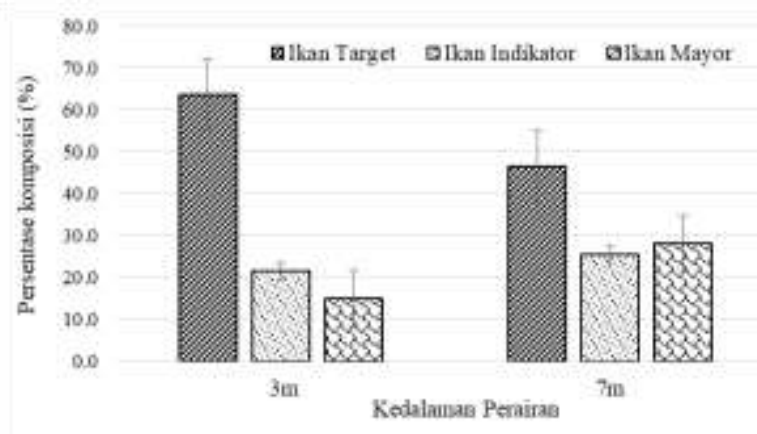

Gambar 4. Komposisi kelimpahan ikan terumbu karang.
Kondisi keseimbangan komunitas ikan terumbu karang yang diperoleh dengan menggunakan analisis indeks keanekaragaman $\left(\mathrm{H}^{\prime}\right)$, indeks keseragaman $(\mathrm{E})$ dan indeks dominansi (C) disajikan pada Tabel 4. Secara keseluruhan, nilai $\mathrm{H}^{\prime}$ sumber daya ikan terumbu karang di lokasi penelitian pada perairan dengan kedalaman $3 \mathrm{~m}$ berkisar 1,56-2,99 yang termasuk dalam kategori keanekaragaman spesies kecil hingga sedang. Pada perairan dengan kedalaman $7 \mathrm{~m}$ memiliki nilai $\mathrm{H}^{\prime}$ berkisar 1,63-2,66 yang juga termasuk dalam kategori keanekaragaman spesies kecil hingga sedang. Nilai E berkisar 0-1, yang mana semakin tinggi nilai $\mathrm{E}$ tersebut mendekati 1 maka kondisi ekologi disuatu perairan semakin stabil. Berdasarkan nilai $\mathrm{E}$ pada Tabel 3 menunjukkan bahwa struktur komunitas ikan terumbu karang pada kedalaman $3 \mathrm{~m}$ maupun $7 \mathrm{~m}$ di pesisir timur Kabupaten Biak Numfor tidak terdistribusi secara merata. Nilai E pada kedalaman $3 \mathrm{~m}$ antara 0,14-0,90. Lokasi yang termasuk dalam kategori keseragaman tinggi dan komunitas ikan dalam kondisi stabil yaitu Anggraidi 1, Anggaraidi 3, Anggraidi 4, Ruar, dan Ibdi, sedangkan komunitas ikan di lokasi yang lainnya dalam kondisi tidak stabil dan masuk dalam kategori keseragaman sedang hingga rendah. Nilai E pada kedalaman $7 \mathrm{~m}$ antara $0,51-0,87$ yang termasuk dalam kategori sedang dan tinggi. Lokasi yang termasuk kategori ke-seragaman tinggi dan kondisi stabil yaitu Anggraidi 1, Anggraidi 3, Anggraidi 4, Ibdi, Soryar, Aryom 1, Aryom 2 dan Opiaref 2, sedangkan lokasi yang lainnya termasuk kategori keseragaman rendah dan kondisi tidak stabil.

Tabel 4. Kelimpahan dan jumlah spesies ikan terumbu karang pada lokasi penelitian.

\begin{tabular}{cccccccccccc}
\hline \multirow{2}{*}{ Lokasi } & \multicolumn{2}{c}{$\begin{array}{c}\text { Jumlah Ikan } \\
\text { (ekor) }\end{array}$} & \multicolumn{2}{c}{$\begin{array}{c}\text { Jumlah } \\
\text { Spesies }\end{array}$} & \multicolumn{2}{c}{$\mathrm{H}^{\prime}$} & \multicolumn{2}{c}{$\mathrm{E}$} & \multicolumn{2}{c}{$\mathrm{C}$} \\
\cline { 2 - 13 } & $3 \mathrm{~m}$ & $7 \mathrm{~m}$ & $3 \mathrm{~m}$ & $7 \mathrm{~m}$ & $3 \mathrm{~m}$ & $7 \mathrm{~m}$ & $3 \mathrm{~m}$ & $7 \mathrm{~m}$ & $3 \mathrm{~m}$ & $7 \mathrm{~m}$ \\
\hline Anggraidi 1 & 122 & 82 & 18 & 17 & 2,46 & 2,45 & 0,85 & 0,87 & 0,11 & 0,12 \\
Anggraidi 2 & 233 & 189 & 30 & 24 & 2,61 & 2,35 & 0,14 & 0,74 & 0,77 & 0,16 \\
Anggraidi 3 & 228 & 221 & 28 & 27 & 2,99 & 2,64 & 0,90 & 0,80 & 0,06 & 0,11 \\
\hline
\end{tabular}




\begin{tabular}{lccccccccccc}
\hline \multirow{2}{*}{ Lokasi } & \multicolumn{2}{c}{$\begin{array}{c}\text { Jumlah Ikan } \\
\text { (ekor) }\end{array}$} & \multicolumn{2}{c}{$\begin{array}{c}\text { Jumlah } \\
\text { Spesies }\end{array}$} & \multicolumn{2}{c}{$\mathrm{H}^{\prime}$} & \multicolumn{2}{c}{$\mathrm{E}$} & \multicolumn{3}{c}{$\mathrm{C}$} \\
\cline { 2 - 13 } & $3 \mathrm{~m}$ & $7 \mathrm{~m}$ & $3 \mathrm{~m}$ & $7 \mathrm{~m}$ & $3 \mathrm{~m}$ & $7 \mathrm{~m}$ & $3 \mathrm{~m}$ & $7 \mathrm{~m}$ & $3 \mathrm{~m}$ & $7 \mathrm{~m}$ \\
\hline Anggraidi 4 & 34 & 60 & 12 & 12 & 1,82 & 2,04 & 0,73 & 0,82 & 0,28 & 0,17 \\
Ruar & 231 & 194 & 26 & 23 & 2,38 & 2,05 & 0,73 & 0,65 & 0,15 & 0,25 \\
Ibdi & 140 & 225 & 25 & 23 & 2,72 & 2,66 & 0,84 & 0,85 & 0,09 & 0,09 \\
Soryar & 224 & 71 & 26 & 20 & 2,14 & 2,42 & 0,66 & 0,81 & 0,23 & 0,15 \\
Aryom 1 & 116 & 179 & 22 & 21 & 2,30 & 2,27 & 0,74 & 0,75 & 0,19 & 0,17 \\
Aryom 2 & 547 & 161 & 26 & 16 & 1,65 & 2,14 & 0,51 & 0,77 & 0,34 & 0,17 \\
Opiaref 1 & 238 & 255 & 22 & 19 & 1,98 & 1,82 & 0,64 & 0,62 & 0,26 & 0,26 \\
Opiaref 2 & 279 & 97 & 26 & 17 & 2,24 & 2,20 & 0,69 & 0,78 & 0,19 & 0,17 \\
Yensama & 400 & 525 & 25 & 25 & 1,56 & 1,63 & 0,49 & 0,51 & 0,41 & 0,33 \\
\hline
\end{tabular}

Secara keseluruhan, nilai C pada kedalaman $3 \mathrm{~m}$ dan $7 \mathrm{~m}$ termasuk kategori rendah dengan nilai 0,06-0,41. Pada kedalaman $3 \mathrm{~m}$ dan kedalaman $7 \mathrm{~m}$ nilai $\mathrm{E}$ berkisar 0,09-0,33. Nilai $\mathrm{C}$ dengan kategori dominansi tinggi hanya ditemukan pada kedalaman $3 \mathrm{~m}$ di Anggraidi 2.

\subsection{Hubungan Komunitas Karang dengan Komunitas Ikan Terumbu Karang}

Tutupan komunitas karang dengan jumlah individu ikan karang pada kedalaman $3 \mathrm{~m}$ memiliki hubungan linier, tetapi kekuatan korelasinya lemah $(r=0,26)$, sedangkan hubungan antara tutupan komunitas karang dengan jumlah jenis ikan karang memiliki korelasi yang positif dengan nilai koefisien korelasi (r) sebesar 0,58. Nilai ini merupakan nilai korelasi yang cukup rendah, namun nilai positif memiliki arti bahwa besarnya perubahan terhadap persentase tutupan komunitas karang searah dengan besarnya perubahan terhadap jumlah jenis ikan. Berdasarkan uji t terhadap nilai $r$ sebesar 0,58 diperoleh $t_{\text {hit }}=2,27$ dan $\mathrm{t}_{\mathrm{tab}}=2,23$ $(\alpha=0,05)$. Hasil uji tersebut menunjukkan bahwa $t_{\text {hit }}>\mathrm{t}_{\text {tab }}$ yang berarti bahwa ada korelasi antara tutupan komunitas karang dengan jenis ikan karang. Terumbu karang merupakan habitat yang menyokong kehidupan komunitas ikan sehingga ikan sangat bergantung pada tutupan komunitas karang. Penurunan jumlah individu dan jenis ikan merupakan respon terhadap degradasi tutupan komunitas karang yang merupakan habibat ikan terumbu karang. Menurut penelitian yang dilakukan oleh Jones et al. (2004) menyebutkan bahwa $11 \%$ dari 538 spesies ikan karang memiliki hubungan erat dengan karang hidup.

Korelasi antara tutupan komunitas karang dengan jumlah individu ikan karang $(\mathrm{r}=0,67)$ maupun tutupan komunitas karang dengan jumlah jenis ikan $(\mathrm{r}=0,60)$ pada kedalaman $7 \mathrm{~m}$ memiliki korelasi positif. Besarnya perubahan terhadap tutupan komunitas karang searah dengan besarnya perubahan terhadap jumlah individu ikan karang maupun dengan jumlah jenis ikan. Hasil uji t terhadap korelasi antara tutupan komunitas karang dengan jumlah individu ikan diperoleh $t_{\text {hit }}=2,89$ dan $t_{\text {tab }}=2,23$ $(\alpha=0,05)$. Hasil uji t terhadap korelasi antara tutupan komunitas karang dengan jumlah jenis ikan diperoleh $t_{\text {hit }}=2,42$ dan $t_{\text {tab }}=2,23$ $(\alpha=0,05)$. Kedua hasil uji menunjukkan bahwa $t_{\text {hit }}>t_{\text {tab }}$ yang berarti bahwa ada korelasi antara tutupan komunitas karang dengan jenis ikan karang dan antara tutupan komunitas karang dengan jumlah individu ikan karang. Hal tersebut didukung oleh Komyakova et al. (2013) yang menyatakan bahwa terdapat hubungan positif antara tutupan komunitas karang dengan kelimpahan jenis ikan. Kekayaan jenis karang memiliki hubungan positif yang lebih kuat dengan kekayaan jenis ikan, sedangkan 
tutupan komunitas karang memiliki hubungan positif yang kuat dengan total kelimpahan atau jumlah total individu ikan. Kelimpahan beberapa spesies ikan didorong oleh ketersediaan spesies karang tertentu. Kelimpahan total ikan memiliki hubungan linier yang signifikan dengan kekayaan spesies karang. Tutupan karang memiliki efek penting pada keanekaragaman ikan karang, kelimpahan dan komposisi spesies.

Menurut Kuffner et al. (2007) ikan terumbu karang lebih berkaitan dengan komunitas karang dibandingkan dengan variabel fisik lingkungan perairan. Asosiasi erat terjadi antara tutupan komunitas karang dengan jumlah jenis ikan terumbu karang pada kedalaman $3 \mathrm{~m}$ dan pada kedalaman 7 $\mathrm{m}$ asosiasi erat terjadi antara tutupan komunitas karang dengan jumlah ikan terumbu karang. Munday (2004) menambahkan bahwa penurunan kelimpahan karang menyebabkan penurunan kelimpahan ikan karang.

\section{KESIMPULAN}

Tutupan komunitas karang berasosiasi positif dengan jumlah individu ikan maupun jumlah jenis ikan karang pada kedalaman $3 \mathrm{~m}$ maupun kedalaman $7 \mathrm{~m}$.

\section{UCAPAN TERIMA KASIH}

Ucapan terima kasih disampaikan kepada Biro Otonomi Khusus Pemerintah Daerah Provinsi Papua yang telah membiayai penelitian ini.

\section{DAFTAR PUSTAKA}

Dinas Kelautan dan Perikanan [DKP]. 2014. Laporan Pendahuluan Penyusunan Dokumen Rencana Pengelolaan Kawasan Konservasi Daerah Kabupaten Biak Numfor. DKP Kabupaten Biak Numfor

Edgar, G.J., N.S. Barrett, and A.J Morton. 2004. Biases associated with the use of underwater visual census techniques to quantify the density and size-structure of fish populations. $J$. Experimental Marine Biology and Ecology, 308(2): 269-290. http://doi.org/10.1016/j.jembe.2004.0 3.004

Falcon, M., M. Pinault, D. Obura, S. Pioch, K. Pothin, L. Bigot, R. Garnier, and J.P. Quod. A comparative study of the accuracy and effectiveness of line and point intercept transect methods for coral reef monitoring in the southwestern Indian Ocean Islands. 2015. J. Ecological Indicators, 60: 1045-1055.

http://doi.org/10.1016/j.ecolind.2015. 09.005

Giyanto, A.E.W. Manuputty, M. Abrar, R.M. Siringoringo, S.R. Suharti, K. Wibowo, I.N. Edrus, U.Y. Arbi, H.A.W. Cappenberg, H.F. Sihaloho, Y. Tuti dan D. Zulfianita. 2014. Panduan monitoring kesehatan terumbu karang: terumbu karang, ikan karang, megabentos dan penulisan laporan. Suharsono, Sumadhiharga OK, editor. Jakarta (ID): CRITC, COREMAP, LIPI. Jakarta. ISBN 978-979-3378-84-8.

Gomez, E.D., and H.T. Yap. 1988. Monitoring reef condition. In: Kenchington, R.A and B.E.T. Hudson (ed). Coral Reef Management Hand Book. UNESCO Regional Office for Science and Technology for southeast Asia, Jakarta.

Guan, Y., S. Hohn, and A. Merico. 2015. Suitable environmental ranges for potential coral reef habitats in the tropical ocean. J. Plos One, 10(6): $\mathrm{e} 0128831$.

http://doi.org/10.1371/journal.pone.01 28831

Jones, G.P., M.I. McCormick, M. Srinivasan, and J.V. Eagle. 2004. Coral decline threatens fish biodiversity in marine reserves. In: Paine, R.T $(e d)$. 
Proceedings of the National Academy of Sciences of the United States of America, 2004 May 25 , 101(21): 8251-8253.

http://doi.org/10.1073/pnas.04012771 01

Khairudi, D. 2016. Evaluasi Pengelolaan Zona Inti Berbasis Sistem Ekologi Terumbu Karang di Kabupaten Biak Numfor [Tesis]. Sekolah Pascasarjana IPB. Bogor.

Komyakova, V., P.L. Munday, and G.P. Jones. 2013. Relative importance of coral cover, habitat complexity and diversity in determining the structure of reef fish communities. J. Plos One, 8(12): e83178.

http://doi.org/10.1371/journal.pone.00 83178

Kuffner, I.B., J.C. Brock, R. GroberDunsmore, V.E. Bonito, T.D. Hickey, and C.W. Wright. 2007. Relationships between reef fish communities and remotely sensed rugosity measurements in Biscayne National Park, Florida, USA. J. Environ. Biol. Fish, 78: 71-82. http://doi.org/10.1007/s10641-0069078-4
Munday, P.L. 2004. Habitat loss, resource specialization, and extinction on coral reefs. J. Global Change Biology, 10(10): 1642-1647.

http://doi.org/10.1111/j.1365-

2486.2004.00839.x

Odum, E.P. 1971. Fundamentals of Ecology. $3^{\text {rd }}$ ed. W. B. Sanders Company Press. USA. 574 p.

Saila, S.B., V.L. Kocic, and J.W. McManus. 1993. Modelling the effects of destructive fishing practices on tropical coral reefs. J. Marine Ecology Progress Series, 94(1): 5160.

http://doi.org/10.3354/meps094051

Turner, J.R., D. Vousden, R. Klaus, C.H. Satyanarayana, D. Fenner, K. Venkataraman, P.T. Rajan, N.V.S. Rao, J.R.B. Alfred, Ramakrishna, and C. Raghunathan. 2009. Coral Reef Ecosystem of Andaman Islands Remote Sensing and Rapid Site Assessment Survey. Rec. zool. Surv. India, Occ, 301: 1-132.

$\begin{array}{ll}\text { Received } & : 17 \text { December } 2018 \\ \text { Reviewed } & : 12 \text { February } 2019 \\ \text { Accepted } & : \text { O5 December } 2019\end{array}$


